\title{
Determinants of Foreign Direct Investment Inflow to Ethiopia: Time Series Evidence (ARDL Approach)
}

\author{
Deresse Dalango \\ Department of Economics, Wolaita Sodo University, Ethiopia
}

\begin{abstract}
In low income country foreign direct investment is taken as the next best alternative source to fill the gap between domestic savings and the required investment for economic growth. While its inflows to Ethiopia are the lowest by a wide margin both in actual quantity and as a proportion of gross national product (GNP). This study deals the empirical relation between FDI inflow and its determinants in Ethiopia by employing Autoregressive distributed lag model for the time period covering from 1981 to 2018. The stationarity properties of the data was detected using Augmented Dickey-Fuller (ADF) and Phillip-Perron (PP) unit root test and the result indicates all the variables are stationary at level and first difference calling the effectiveness of ARDL model. The ARDL bound test used to test the existence of long-run link among the variables and the result confirmed that there is long run relationship among FDI and independent variables. The results indicated that the FDI flows to Ethiopian economy are determined by the degree of trade openness; domestic market size proxied by per capita GDP; domestic bank credit; rate of inflation; human capital and official exchange rate in the long-run and trade openness; rate of inflation and official exchange rate in its short run dynamics. The policy which creates favorable environments for domestic credit institution; predictable official exchange market and uninflated domestic price situation enables to harvest the highest possible expected benefits from FDI inflow.
\end{abstract}

Keywords: FDI, ARDL, Bound test, ECM, Ethiopia

DOI: $10.7176 /$ IAGS/85-01

Publication date:August $31^{\text {st }} 2020$

\section{Introduction}

Investment whether public or private, domestic or foreign is vital to the socio-economic transformation of economy respective of the countries level of development. The international economic integration which gained momentum since the beginning of the 1990s has led to a significant flow of foreign direct investment towards developing countries. The FDI flow rose an annual rate of \$2.4 billion in 1962 to $\$ 35$ billion in 1990 and reached $\$ 334$ billion in 2005 , and $\$ 600$ billion in 2005 and in 2015 it reached to $\$ 1.8$ trillion in the world total (UNCTAD, 2013). Attracting Foreign Direct Investment (FDI) is generally seen as an integral part of the development policy mix of successful emerging economies that leads the way to the required sustained economic transformation.

Foreign direct investment (FDI) in low income country has the potential to be beneficial for both the host countries and the multi-national corporations (MNCs) or other entities seeking to invest. Foreign investors benefits from utilizing their assets and resources efficiently, while host country benefits from acquiring technologies and getting involved in international production and trade networks. FDI assists to the recipient countries by providing capital, foreign exchange, technology, competition and by enhancing access to foreign markets (World Bank, 1999; Crespo and Fontura, 2007; Romer, 1993; UNCTAD, 1991). Hence, most of the developing countries are competing with each other to attract striking amount of FDI by adopting different promotional policies, such as by liberalizing trade regimes, establishing special economic zones and by offering incentives to the foreign investors(Ruffin, 1993). As result developing countries have been receiving increasingly greater amounts of FDI, accounting for 52\% of global FDI inflows in 2012(UNCTAD, 2013). The highest amounts of FDI in 2012, were received by Mexico in Central America, Indonesia in Southeast Asia, Nigeria in Africa, Turkey in West Asia, Brazil in South America, India in South Asia, and China in East Asia (UNCTAD, 2013).

In Ethiopia, there has been the wide gap between domestic investment and savings due to the low levels of income and domestic savings. Between 1990 and 1997, gross domestic investment as a proportion of GDP rose from $12 \%$ to $19 \%$, while gross domestic savings remained at the same rate (UNCTAD, 2002). This saving gap can be filled by loans and development assistance from bilateral and multilateral agencies such as the World Bank or by private foreign investment. While, loans and development assistance have been declining from time to time and hence cannot grant growth and development plans in low income country like Ethiopia. It has been reported that development assistance to Sub-Saharan Africa declined from $\$ 17$ billion in 1990 to $\$ 10$ billion (Asiedu, 2003). Thus, FDI is the exciting alternative source of foreign capital for these countries. In view of this important role of FDI, it is critical to understand the principal determinants of FDI in Ethiopia.

Many scholars out lined multidimensional factors that can influence the flow of FDI and their finding indicates that there were no a cross-cutting hindrances throughout different countries. Most of FDI inflow to 
African country determined by availability of extractive natural resource endowments like oil and minerals sectors (Morisset, 2000; Basu and Srinivasan, 2002). However, creation of favorable economic, social and political environment, Market liberalisation, export orientation, tax and other investment incentives have undishearten value to attract FDI to Africa (UNCTAD, 1998; Basu and Srinivasan, 2002). Several investigation found the positive influence of openness to trade, measured by exports plus imports to GDP on FDI flow (Chakrabarti's, 2001; Morisset, 2000; Salisu, 2003 and Kandieru and Chitiya (2003). According to Wheeler and Mody (1992) and Singh and Jun (1995) political risk and administrative efficiency have insignificant effect on FDI inflow, while for other inquiry political strikes and riots and regular constitutional changes in government significantly determine flow of FDI ( Root and Ahmed,1979; and Schneider and Frey ;1985). According to Chakrabarti (2001), the size of domestic market, which is measured by per capita GDP, has positive and significant effect on FDI. While, if a firm is export-oriented and not market seeking, the size of domestic market will not be an important determinant of FDI (Root and Ahmed, 1979). On the other hand, Salisu (2003) found insignificant effect of domestic market on FDI inflow. These argumentative finding calls further investigation on main determinants of FDI inflow to low income country particular Ethiopia.

Most of empirical analysis in different under developed countries including Ethiopia applied conventional least square and descriptive methods to show relation between FDI inflow and its determinate's (shown in literature review). However, in case of time variant data, applying the model which has superior expedient in testing long and short run link between variables will be logical. The Autoregressive Distributive Lag (ARDL) model has more advantage over these above mentioned methods in this case. Hence, this study fills the gap by applying ARDL model to perform the short- and long-run link between FDI inflow to Ethiopia and its determinants covering from the year 1981 to 2018.

\section{Literature Review}

The balance of payment accountants define FDI as any flow of lending to, or purchase of ownership in, a foreign enterprise that is largely owned by the residents (usually firms) of the investing country (Thomas A. and Peter H. 2000). An investment by a foreign investor is regarded as FDI if the direct investor holds at least 10 percent of the ordinary share or voting power of a firm. Silajdzic and Mehic (2015) postulate that foreign direct investment positively lift economic growth through knowledge spillovers in transition countries; technological and innovative efforts transmission which are suggested to be essential factor sustaining growth performance.

The general level of investment is low in developing country due to low level of domestic saving and this in turn leads to low level of economic growth. As a result, foreign direct investment is taken as the next best alternative source to fill the gap between domestic savings and the required investment for economic growth aweless. Beside direct benefit of FDI, the government's budget deficits can also be minimized by collecting profit-tax from foreign direct investors (Todaro, 1992, Solomon 2008, Teshome 2010). FDI can also play important role by creating employment opportunities and by integrating the host-country economy in to the world economy (OECD, 2002). However, some scholars forward the negative out comes of FDI in that the failures of foreign firms to reinvest the profit they generate in the host country; hamper the growth of domestic enterprises and domestic investment by importing the input and intermediate product from their subsidiaries in other countries. FDI might also inhibit the development of indigenous skills as the result of multinational companies' dominance over local enterprises (Todaro, 1992, Solomon 2008, Teshome 2010).

Even though, the contribution of FDI is high for the country's economy, its inflows to Ethiopia are the lowest by a wide margin both in actual quantity and as a proportion of gross national product (GNP). The amount of FDI coming to Ethiopia is small in absolute quantity; it also is significantly small compared with domestic investment and small compared to FDI inflows of in comparable neighboring countries (Berhanu 1999). The average annual FDI flow to Ethiopia from 2003 to 2006 were only \$399 million, which accounts only $1.56 \%$ of FDI flows to Africa. Ethiopia share for only 1\% of African inward FDI stock while representing to $9 \%$ of the population of the content. The per capita inflows were $\$ 5$ in 2006 compared with $\$ 39$ for African countries as a whole (Yared, 2006). The multidimensional factors including socio-economic and administrative inconvenience may rise reason for low level of FDI in flow to Ethiopia.

The empirical study by Lemi and Asefa (2001) examines the impact of economic and political uncertainty on foreign direct investment flow to 31 African countries. Their finding indicates that beside political stability and government policy commitment, the economic factors such as labour, trade connection, size of the export sector, external debt, and market size of the countries are significant determinants of FDI flows to African countries. In the same manner Agodo (1975) found the significant influence of political stability and favourable investment climate, the size of the domestic market, the presence of needed raw materials, and infrastructure on private investors' corporate decisions to undertake manufacturing investments in Africa. The outward oriented developing economies have been considered as successful in attracting foreign direct investment flows (Hein, 1993 and Dollar, 1992). According to Morriset (2000) and Chakrabarti's (2001) openness to trade measured by exports plus imports to GDP has positive effect to receive FDI to low income country particular Africa. 
Getinet and Hirut (2005) found the positive influence of growth rate of real GDP, export orientation, and liberalization and the adverse effect of macroeconomic instability and poor infrastructure on FDI inflow to Ethiopia. They applied a cross section fixed effect Least Squares to analysis the link between FDI and independent variables. According to Birhanu (1999), higher and unpredictable inflation rate, availability and reliability of telecommunication services, developed and adequate road and air transport services, reliable water and electricity supply facilities have big importance to attract FDI to Ethiopia.

\section{Data and Methodology}

The data source for this analysis were obtained from World Bank World development indicator and international monetary fund (IMF) world economic outlook database.

Prior to analyzing the dynamic relationship between time series variables using any available model, it is important to determine the characteristics of the individual series (Gujarati, 2004). Hence, unit root tests for stationary are examined on the levels and first differences for all variables using the most common unit root tests, which is the Augmented Dickey-Fuller (ADF) and the Philip-Perron tests (PP). Usually ADF yields superior results than PP test, if the data set has no missing observations and structural breaks while PP test also yields superior results than ADF test, if the dataset have some missing observations and have structural breaks (Green, 2003). In this research both ADF and PP test were employed to look stationarity of series and order of integration.

\section{The Autoregressive Distributed Lag Model (ARDL)}

Many of prior researchers had been used ordinary least square methods; the Johansen (1988) co-integration and Engle-Granger causality technique to determine the long-term relationships between time variant variables. While, recent studies by Pesaran et al. (2001), Pesaran and Shin (1999), and Nayaran (2004), who introduced an alternative co-integration technique known as the 'Autoregressive Distributed Lag (ARDL)' bound test. Using ARDL model also called 'Bound Testing Approach' has several advantages over other alternative methods such as conventional Engle-Granger two-step procedure, Maximum likelihood methods of cointegration (Johansen and Jtiselius, 1990).

According to Pesaran et al. (2001) and Nayaran (2004), ARDL model is the more statistically significant approach to determine the co-integration relation in small samples than Johansen co-integration techniques, which require large data samples for valid estimation of the parameters. This means that the model avoids the problem of biases that arise from small sample size. In addition, ARDL model is free from the endogeneity problem. In this approach of Pesaran and Shin (1999) maintain that modeling ARDL with the appropriate number of lags will address autocorrelation and endogeneity problems, because it is possible that different variables have different optimal numbers of lags, whereas in Johansen-type models this is not possible rather take the same lag length for all variables. Most importantly, the ARDL estimation can be applied whether the regressors are purely ordered zero $[\mathrm{I}(0)]$, purely order one $[\mathrm{I}(1)]$, or a mixture of both. While other cointegration techniques require all of the regressors to be integrated of the same order. Hence, we employed ARDL approach because relatively the sample used in the study is small.

Therefore, ARDL model can be specified as:

$$
\begin{aligned}
\Delta \ln \left(F D I_{t}\right)= & B_{o}+B_{1} \ln \left(F D I_{t-1}\right)+B_{2} \ln \left(\mathrm{GDPC}_{t-1}\right)+B_{3} \ln \left(\mathrm{BCR}_{t-1}\right)+B_{4} \ln \left(\mathrm{TOPG}_{t-1}\right) \\
& +B_{5} \ln \left(\mathrm{HEDUCG}_{t-1}\right)+B_{6} \ln \left(\mathrm{INFR}_{t-1}\right)+B_{7} \ln \left(\mathrm{EXR}_{t-1}\right)+\sum_{i=1}^{s} \alpha_{i} \Delta \ln \left(\mathrm{FDI}_{t-i}\right) \\
& +\sum_{j=1}^{r} \alpha_{j} \Delta \ln \left(\mathrm{GDPC}_{t-j}\right)+\sum_{k=1}^{s} \alpha_{k} \Delta \ln \left(\mathrm{BCR}_{t-k}\right)+\sum_{l=1}^{v} \alpha_{l} \Delta \ln \left(\mathrm{TOPG}_{t-l}\right) \\
& +\sum_{m=1}^{y} \alpha_{m} \Delta \ln \left(\mathrm{HEDUCG}_{t-m}\right)+\sum_{n=1}^{x} \alpha_{n} \Delta \ln \left(\mathrm{INFR}_{t-n}\right)+\sum_{p=1}^{w} \alpha_{p} \Delta \ln \left(\mathrm{EXR}_{t-p}\right) \\
& +\varepsilon_{t}
\end{aligned}
$$

Where:- FDI- Foreign direct investments in US dollar; GDPC- per capita GDP;BCR- domestic bank credit; INFR- Inflation rate; TOPG- Trade openness (import + export as \% of GDP);HEDUCG-government expenditure on health and education and EXR- Official Exchange Rate. Based on economic theory and the prior empirical finding, the expected signs of the coefficients are $\beta_{2}(\bar{F}), \beta_{3}>0, \beta_{4}>0, \beta_{5}>0, \beta_{6}>0, \beta_{7}>0$. The symbol $\Delta$ is the first difference operator, $\mathrm{q}, \mathrm{r}, \mathrm{s}, \mathrm{v}, \mathrm{y}$, $\mathrm{x}$, and $\mathrm{w}$ are the lag length with their respective variables and $\varepsilon_{t}$ error term which is assumed to be serially uncorrelated; $\beta_{1}, \beta_{2}, \beta_{3}, \beta_{4}, \beta_{5}, \beta_{6}$ and $\beta_{7}$ are the coefficients that measure long-run elasticities between the 
variable. Whereas $\alpha_{\mathrm{i}}, \alpha_{\mathrm{j}}, \alpha_{\mathrm{k}}, \alpha_{\mathrm{l}}, \alpha_{\mathrm{m}}, \alpha_{\mathrm{n}}$, and $\alpha_{\mathrm{p}}$ indicates coefficients that measure short-run elasticities among the variables.

The first step involved in ARDL model is to test the null hypothesis of no cointegration relationship which is defined as $H_{\mathrm{O}}=\beta_{1}=\beta_{2}=\beta_{3}=\beta_{4}=\beta_{5}=\beta_{6}=\beta_{7}=0$ against the alternative hypothesis of $H_{1} \neq \beta_{1} \neq \beta_{2} \neq \beta_{3} \neq \beta_{4} \neq \beta_{5} \neq$ $\beta_{6} \neq \beta_{7} \neq 0$ of the existence of co-integrating relationship between the variables.

The diagnostic test such as Heteroscedasticity test (Brush-Pagan \& Godfray LM test), Serial correlation test (Brush \& Godfray LM test), Normality (Jaque-Bera test) and Functional form (Ramsey's RESET) test were undertaken. Similar to residual diagnostic test, the parameter stability test of the model was also conducted. The co-integration test has been undertaken on the F-statistic with help of the bound test of ARDL. Having, the cointegration of the series, the short-run elasticities can also be derived through constructing the error correction model in the following form:

$$
\begin{aligned}
\Delta \ln \left(G D P_{t}\right)= & B_{o}+\sum_{i=1}^{q} \alpha_{i} \Delta \ln \left(\mathrm{FDI}_{t-i}\right)+\sum_{j=1}^{r} \alpha_{j} \Delta \ln \left(\mathrm{GDPC}_{t-j}\right)+\sum_{k=1}^{s} \alpha_{k} \Delta \ln \left(\mathrm{BCR}_{t-k}\right) \\
& +\sum_{i=1}^{v} \alpha_{l} \Delta \ln \left(\mathrm{TOPG}_{t-l}\right)+\sum_{m=1}^{x} \alpha_{m} \Delta \ln \left(\mathrm{HEDUCG}_{t-m}\right)+\sum_{n=1} \alpha_{n} \Delta \ln \left(\mathrm{INFR}_{t-n}\right) \\
& +\sum_{p=1}^{w} \alpha_{p} \Delta \ln \left(\mathrm{EXR}_{t-p}\right)+\rho E C M_{t-1}+\varphi_{t}
\end{aligned}
$$

Where, the variable $\mathrm{ECM}_{\mathrm{t}-1}$ is the error correction term which captures the long- run relationship whereas $\alpha$ 's are the coefficients associated with short-run dynamics of the model coverage to equilibrium.

\section{Estimation Results and Discussion}

\subsection{Unit Root Test Analysis}

In time series investigation it would be vital to ensure a long-run relationship amongst the variables in the model and the stationarity of all variables included. The Augmented Dickey-Fuller (ADF) and Phillip-Perron (PP) test were applied to assess the stationarity of variables in the model and to ensure that none is I (2) or above in which we cannot apply ARDL bounds test to co-integration.

Table-4.1 below designate the ADF test results of the series at the level and first differences with constant only and intercept with linear trend specification so as to capture the variables stationary. The results indicate, all the variables except foreign direct investment (FDI); bank credit (BCR) and exchange rate (EXR), are become stationary at the first difference at one percent level of significance. While foreign direct investment (FDI) was stationary at level with five percent significance with intercept, and intercept with trend and bank credit (BCR) was stationary at level in five percent level of significance intercept with trend but it was stationary at one percent in the first difference if we exclude linear trend (table-4.1). Moreover, the results under Phillip-Perron (PP) unit root tests indicates that Per capita GDP; trade openness; and government expenditure on education and health service as percentage of GDP become stationary at the first difference with intercept, and intercept with trend at one percent level of significance. On the other hand, FDI; bank credit and inflation rate are stationary at level under intercept with trend in $1 \%$ level of significance (table-4.1).

The test result evident that none of the variables was I(2) or above and hence we moved on with the ARDL co-integration technique since it is capable of dealing with whether all variables are $\mathrm{I}(0)$ or all are $\mathrm{I}(1)$ or a mixture of both. This suggesting to proceed co-integration test using the ARDL approach (bounds test approach of co-integration) developed by Pesaran et al. (2001). 
Table 4.1. Augmented Dickey-Fuller (ADF) and Phillip-Perron (PP) unit root tests

\begin{tabular}{|c|c|c|c|c|c|c|}
\hline \multicolumn{7}{|c|}{ ADF-test results } \\
\hline \multirow[b]{2}{*}{ Variables } & \multicolumn{2}{|c|}{ With intercept } & \multicolumn{4}{|c|}{ With intercept and trend } \\
\hline & At level & $\begin{array}{c}1^{\text {st }} \\
\text { difference }\end{array}$ & $\begin{array}{l}\text { Order of } \\
\text { integration }\end{array}$ & At level & $\begin{array}{c}1^{\text {st }} \\
\text { difference }\end{array}$ & $\begin{array}{l}\text { Order of } \\
\text { integration }\end{array}$ \\
\hline LNFDI & $-2.962594 * *$ & - & $\mathrm{I}(0)$ & $-3.936908 * *$ & - & $\mathrm{I}(0)$ \\
\hline LNGDPC & 2.018139 & $-3.639407 * *$ & $\mathrm{I}(1)$ & -0.800947 & $-6.172972 * * *$ & $\mathrm{I}(1)$ \\
\hline LNBCR & 0.677631 & $-6.225552 * * *$ & $\mathrm{I}(1)$ & $-3.742070 * *$ & - & $\mathrm{I}(0)$ \\
\hline TOPG & -0.942869 & $-5.256635 * * *$ & $\mathrm{I}(1)$ & -1.496520 & $-5.195272 * * *$ & $\mathrm{I}(1)$ \\
\hline HEDUCG & -0.951118 & $-5.828173 * * *$ & $\mathrm{I}(1)$ & -2.702304 & $-5.735180 * * *$ & $\mathrm{I}(1)$ \\
\hline INFR & -1.930238 & $-8.616520 * * *$ & $\mathrm{I}(1)$ & -2.146591 & $-8.483239 * * *$ & $\mathrm{I}(1)$ \\
\hline EXR & 2.569133 & $-1.516854^{*}$ & $\mathrm{I}(1)$ & 0.522260 & $-3.210766^{*}$ & $\mathrm{I}(1)$ \\
\hline \multicolumn{7}{|c|}{ PP-test results } \\
\hline LNFDI & -1.356326 & $-12.08385 * * *$ & $\mathrm{I}(1)$ & $-4.111692 * *$ & - & $\mathrm{I}(0)$ \\
\hline LNGDPC & 1.814654 & $-4.074374 * * *$ & $\mathrm{I}(1)$ & -0.643132 & $-5.355314 * * *$ & $\mathrm{I}(1)$ \\
\hline LNBCR & 0.494012 & $-6.188462 * * *$ & $\mathrm{I}(1)$ & $-3.668167 * *$ & - & $\mathrm{I}(0)$ \\
\hline TOPG & -0.942869 & $-5.266764 * * *$ & $\mathrm{I}(1)$ & -1.636747 & $-5.201836^{* * *}$ & $\mathrm{I}(1)$ \\
\hline HEDUCG & -0.617504 & $-6.323414 * * *$ & $\mathrm{I}(1)$ & -2.786256 & $-6.421540 * * *$ & $\mathrm{I}(1)$ \\
\hline INFR & - & - & $\mathrm{I}(0)$ & - & - & $\mathrm{I}(0)$ \\
\hline & $4.110538 * * *$ & & & $4.425131 * * *$ & & \\
\hline EXR & 3.399546 & $-1.395284 *$ & $\mathrm{I}(1)$ & 0.392595 & $-2.195066^{*}$ & $\mathrm{I}(1)$ \\
\hline
\end{tabular}

Source: Author's Computation Using Eviews 9.0 Package

Note: I () represents order of integration and $* * *, * *$ and $*$ denotes significance at the $1 \%, 5 \%$ and $10 \%$ levels respectively.

\subsection{Diagnostic and Stability Test}

Prior to interpreting the estimation results, the robustness of the ARDL model has been checked through several diagnostic and stability tests statistics. The test results of Jarque-Bera normality test, Ramsey RESET stability test, Breusch-Godfrey Serial Correlation LM test and Breusch-Pagan-Godfrey heteroskedasticity test validates the absence of serial correlation, misspecification of the model, non-normality of the error term, and heteroscedasticity (table-4.2).

Table 4.2 Result of the diagnostic test for ARDL model $(2,2,2,1,1,1,2)$

\begin{tabular}{llll}
\hline Diagnostic Tests & Statistics & Results & Conclusion \\
\hline Heteroskedasticity Test: & F-statistic & 0.814844 & No heteroskedasticity \\
Breusch-Pagan-Godfrey & Prob. F(17,9) & 0.6584 & problem \\
& Prob. Chi-Square(17) & 0.4980 & \\
\hline Breusch-Godfrey Serial & F-statistic & 3.036031 & No serial correlation \\
Correlation LM Test & Prob. & 0.0019 & \\
\hline Ramsey RESET Test & F-statistic $(1,8)$ & 0.007169 & Equation is correctly \\
& Prob. & 0.9346 & specified \\
\hline Multivariate Normality & Jarque-Bera & 0.3118 & Residuals are normal \\
Test & Prob. & 0.8556 & \\
\hline
\end{tabular}

Source: Author's Computation Using Eviews 9.0 Package

Pesaran and Pesaran (2009), outlined the need to analyze the stability of the long-run coefficients in conjunction with the short-run dynamic model.

Accordingly, the parametric stability can be tested using cumulative of the recursive residuals (CUSUM) as well as the cumulative sum of squares of recursive residual (CUSUMQ) (Figures 1 and Figure 2). As procedure, if the blue line crosses redline which is critical line and never returns back between two critical line, we accept the null hypothesis of the parameter instability whereas the cumulative sum goes inside the area (can returns back) between the two critical lines, then there is parameter stability in the short- and long-run. The plots of CUSUM and CUSUMQ test statistics rests neatly within the boundaries at 5\% significant level. Hence, we can conclude that long-run estimates are stable and there is no any structural break. 
Figure 1; CUSUM SQUARE

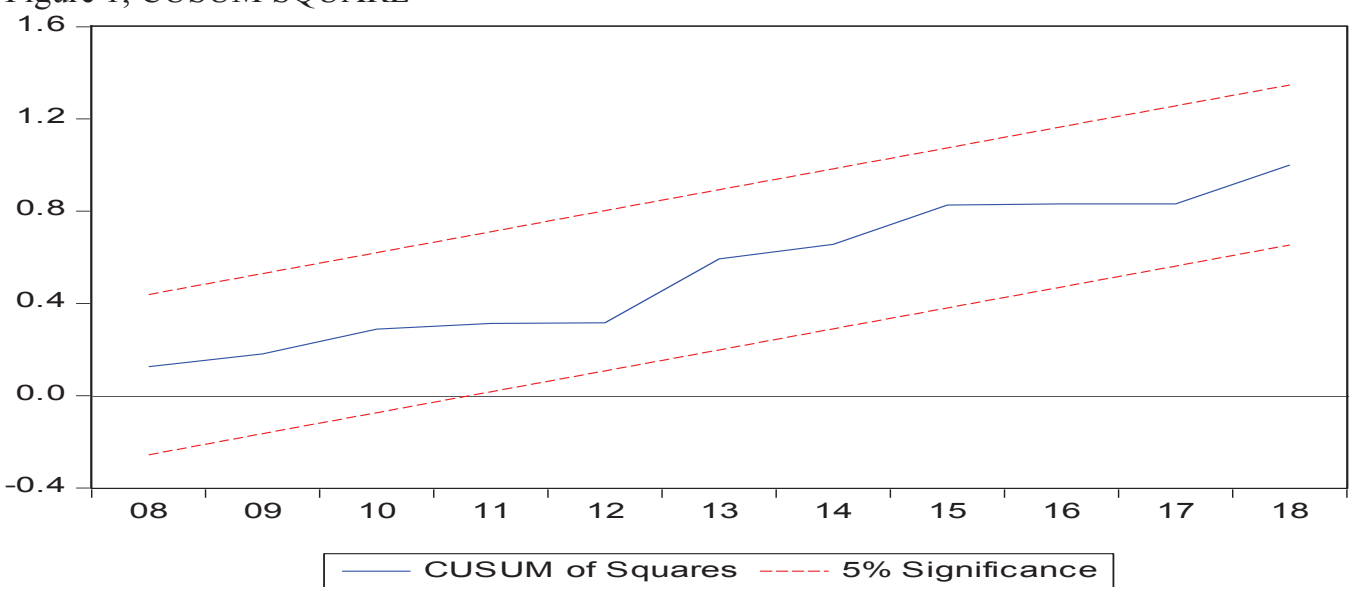

Figure 2: CUSUM

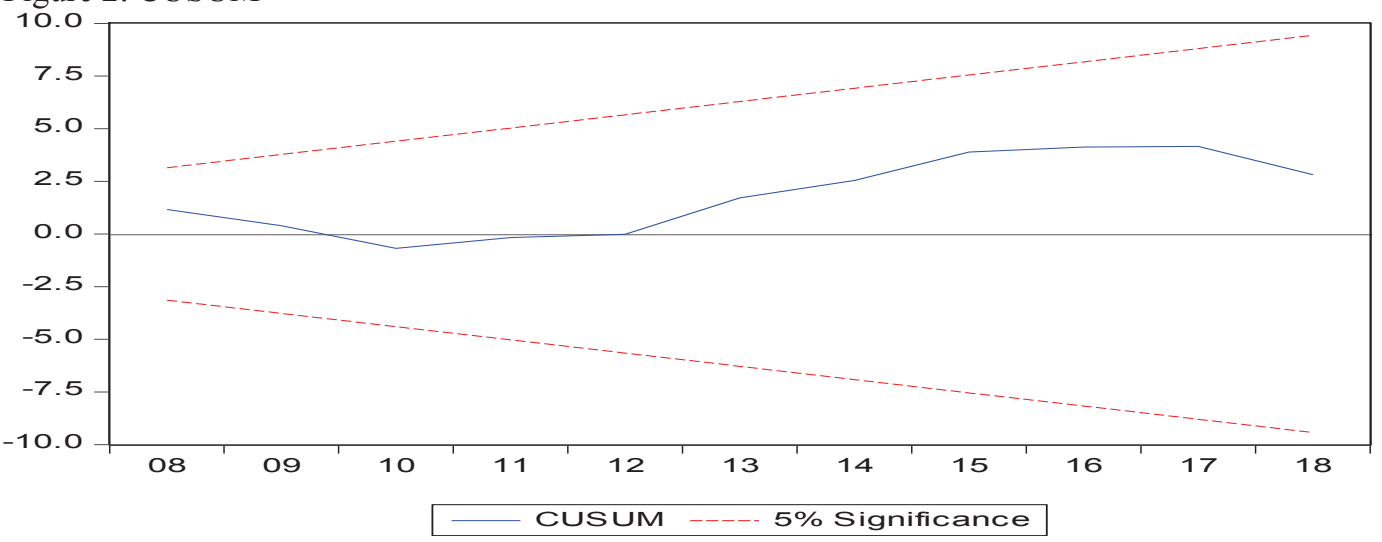

\subsection{Bounds Tests for Co-integration}

Meanwhile, the estimation was proceed employing ARDL model and the optimal lag was selected through Akaike Information criterion (AIC) method. According to Pesaran and Shin (1999) and Nayaran (2004), it was recommended choosing a maximum of 2 lags for annual data series. Accordingly, this analysis set the maximum lag length at 2 years for which are sufficiently long enough for annual data series to investigate the variable relationship and then AIC is applied to choose at the best ARDL model (Lutkephl, 2005).

The criterion for the co-integration bounds test entails the evaluation of F-statistics against the critical values. The results publicized that the test is highly significant at $1 \%$ level (table-4.3). Since the F-statistic (9.97) was above all the upper bound value at $10 \%, 5 \%, 2.5 \%$ and $1 \%$, the null hypothesis of no long run co-integration would be rejected. Consistently, the results confirm the presence of a long-run relationship between the LNFDI and its determinants comprised in this enquiry.

Table 4.3: Bound Test for Co-integration

\begin{tabular}{|c|c|c|}
\hline Significance level & Lower bound & Upper bound \\
\hline $10 \%$ & 2.12 & 3.23 \\
\hline $5 \%$ & 2.45 & 3.61 \\
\hline $2.5 \%$ & 2.75 & 3.99 \\
\hline $1 \%$ & 3.15 & 4.43 \\
\hline
\end{tabular}

Source: Author's Computation Using Eviews 9.0 Package

\section{4. $\quad$ Long-run and Short-run Estimation Results}

The ARDL framework analysis began with establishing co-integration in the long-run coefficients of the equation. Since we conformed, the existence of long-run co-integration relationship among the dependent and independent variables, the remaining steps might be running the appropriate ARDL model to find out the long run coefficients, which is reported in table below. 
Table 4.4 Long-run relationship coefficient estimation ARDL $(2,2,2,1,1,1,2)$

\begin{tabular}{l|c}
\hline VARIABLES & LONG RUN COEFFICIENT \\
\hline TNGDPC & $-5.058033^{* *}$ \\
& $(-2.709525)$ \\
LNBCR & $0.065483^{* *}$ \\
& $(2.560167)$ \\
INFR & $0.802593 * *$ \\
& $(2.296052)$ \\
HEDUCG & $-0.071075^{* * *}$ \\
& $(-7.050458)$ \\
EXR & $0.373260 *$ \\
& $(2.123346)$ \\
C & $0.320401 * * *$ \\
& $(3.877284)$ \\
& $19.026953 * *$ \\
& $(2.359551)$ \\
\hline
\end{tabular}

Source: Author's Computation Using Eviews 9.0 Package

Note: the t-statistic are in parentheses and were significant at $1 \%(* * *), 5 \%(* *)$ and $10 \%(*)$

The long-run coefficient result for our model indicates that domestic market size proxied by per capita GDP (LNGDPC); openness of trade (TOPG); domestic bank credit (LNBCR); rate of inflation (INFR); human capital proxied by government expenditure on health and education (HEDUCG) and official exchange rate (EXR) variables in the model have a statistically significant effect on inflow of FDI to Ethiopia. With exception of per capita GDP and rate of inflation other variables have hypothesized sign and positively attract the FDI flow to country. Contrary to the finding of various scholars these examined the positive effects of domestic market size on flow of FDI, this study found the adverse influence of per capita GDP on FDI in flow to Ethiopia. But, this results was supported by analysis of Root and Ahmed (1979). Accordingly, if a firm is export-oriented and not market seeking, the size of domestic market will not be an important determinant of FDI. If there is macroeconomic stability foreign investors are encouraged to invest more. Since high rate of inflation leads macroeconomic instability, the negative influence of inflation to FDI in this study has theoretical support. The finding is in line with Teshome (2010), who found negative and statistically significant effect of inflation on FDI inflow.

Table 4.5 Short-run error correction model results

\begin{tabular}{l|c}
\hline \multicolumn{1}{l}{ VARIABLES } & SHORT-RUN RESULTS \\
\hline D(LNFDI(-1)) & $0.430293 * *$ \\
D(LNGDPC) & $(2.286310)$ \\
& -3.138230 \\
D(TOPG(-1)) & $(-0.563824)$ \\
& $-0.129042^{* * *}$ \\
D(LNBCR) & $(-3.354500)$ \\
& 0.107936 \\
D(INFR) & $(0.130489)$ \\
& $-0.053789^{* *}$ \\
D(HEDUCG) & $(-3.123558)$ \\
D(EXR) & 0.136980 \\
COINTEQ(-1) & $(0.501187)$ \\
& $0.727183 *$ \\
& $(2.194521)$ \\
& $-2.014625 * * *$ \\
\end{tabular}

Source: Author's Computation Using Eviews 9.0 Package

Note: the t-statistic are in parentheses and were significant at $1 \%(* * *), 5 \%(* *)$ and $10 \%(*)$

Once we accepted the long-run coefficients of the ARDL equation, the short-run ECM model is estimated. If the variables are co-integrated, their dynamic relationship can be specified by an error correction representation in which an error correction term (ECT) computed from the long-run equation must be incorporated in order to capture both the short-run and long-run relationships (Engle and Granger, 1991). The ECT is expected to be statistically significant with a negative sign. The negative sign implies that any shock that occurs in the short-run will be corrected in the long-run. If the error correction term is greater in absolute value, the rate of convergence to equilibrium will be faster (Pesaran \& Pesaran 2009). The coefficient of -2.014 is the (ECMt-1) significant at $1 \%$ level and it signals how fast the variables adjust to equilibrium (table-5). 
The short run dynamics reveals that trade openness (TOPG); rate of inflation (INFR) and official exchange rate (EXR) significantly affect the flow of FDI, while all other variables become insignificant with expected sign (table-5). All other variables shown hypothesized sign but trade openness results unexpected negative sign. This result is also conflicting to economic theory and many of prior empirical finding, which evident the strong positive effect of trade openness to FDI. However, the relation between flow of FDI and trade openness in low income country is debatable, since it is calculated as import plus export to GDP. This result is in line with finding by Seim (2009) and Dunning (1993) who argue that the relationship between trade openness and FDI inflows is complex and can be negative. Abdel and Anass (2018), also found the negative relation between trade openness and FDI in flow in Sudan. It depends on the features of each case separately, because the impact of trade openness on FDI inflow may change according to the inspiration for appealing FDI activities.

\section{Conclusion}

The foreign direct investment positively revitalize economic growth through knowledge spillovers; technological and innovative efforts transmission which are suggested to be essential factor sustaining growth performance in developing economy. This study attempts to study the determinants of FDI inflow to Ethiopia using time series data spanning from 1981 to 2018. The study employed Autoregressive distributed lag model (ARDL) for data collected from World Bank World development indicator and international monetary fund (IMF) world economic outlook database. The stationarity properties of the data was detected using ADF and PP test procedure and the result indicates all the variables are stationary at level and first difference validating the effectiveness of ARDL model. The ARDL bound test used to test the existence of long-run link among the variables and the result confirmed that there is long run relationship among FDI and independent variables. The error correction term has shown expected negative sign and which implies that any shock that occurs in the short-run will be corrected in the long-run.

The long run ARDL estimation results indicated that the FDI flows to Ethiopian economy are positively determined by the degree of trade openness; domestic bank credit; human capital and official exchange rate while adversely influenced by domestic market size proxied by per capita GDP and rate of inflation. According to the short run error correction model result trade openness; rate of inflation and official exchange rate significantly influence the flow of FDI to Ethiopia. Hence, the policy which creates favorable environments for domestic credit institution; predictable official exchange market and uninflated domestic price situation enables to harvest the highest possible expected benefits from FDI inflow.

\section{Bibliography}

Abdel Mahmoud Ibrahim and Anass Hamedelneel . (2018). The impact of trade openness on foreign direct investment in Sudan by sector in the 1990-2017 period: an empirical analysis;

Asiedu, Elizabeth . (2003). Foreign Direct Investment to Africa: The Role of Government Policy, Governance and Political Instability. Department of Economics, University of Kansas.

Basu, Anupam and Srinivasan, Krishna. (2002). Foreign Direct Investment in Africa - Some Case Studies. IMF Working Paper 61.

Berhanu Nega . (1999). Foreign Direct Investment in Ethiopia,.

Chakrabarti Avik . (2001). "The Determinants of Foreign Direct Investment: Sensitivity Analyses of CrossCountry Regressions”, KYKLOS, Vol.54, pp. 89-114.

Crespo, Nuno and Fontoura, Maria Paula . (2007). "Determinant Factors of FDI Spillovers- What do We Really Know?”World Development, Vol. 35, No. 3, pp 410-425.

Dollar David . (1992). "Outward-oriented developing economies really do grow more rapidly: evidence from 95 LDCs 1976-1985. "Economic Development and Cultural Change. Vol. 40, No. 3.

Dunning, J. H. . (1993). Multinational enterprises and the global economy. Addison, Wesley, New York.

Engle, R. F., \& Granger, C. W. . (1991). Long-run economic relationships: Readings in cointegration. Oxford University Press. .

Getnet A. \& Hirut A. . (2006). Determinants of FDI in Ethiopia, time series analysis.

Greene, W.H. . (2003). Econometric Analysis, Fifth Edition, Prentice Hall, N.J. .

Gujarati, D. N. . (2004). Basic econometrics. New York: McGraw-HiII/lrwin.

IMF. (2019). World Economic Outlook (WEO) database; October 2019.

Johansen, S. . (1988). Statistical Analysis of Cointegration Vectors. Journal of Economic Dynamics and Control, 12(2/3), pp. 231-254. DOI: 10.1016/01651889(88)90041-3. .

Johansen, S., and Jtiselius, K. . (1990). Maximum Likelihood Estimation and Inference on Cointegration - with Applications to the Demand for Money. Oxford Bulletin of Economics and Statistics, 52(2), pp. 169-210.

Kandiero Tonia and Chitiga Margaret . (2003). Trade Openness and Foreign Direct Investment in Africa. Paper prepare for the Economic Society of Southern Africa Annual Conference. Department of Economics, University of Pretoria. 
Lemi Adugna and Asefa Sisay . (2001). Foreign Direct Investment and Uncertainty: Empirical Evidence from Africa, Department of Economics, Western Michigan University.

Morisset Jacques . (2000). “Foreign Direct Investment in Africa: Policies Also matter." Transnational Corporation, 9(2), 107-125.

Nayaran K. . (2004). Reformulating Critical Values for the Bounds F-statistics Approach to Cointegration: An Application to the Tourism Demand Model for Fiji. Discussion Papers No: 02, Monash University, Victoria, Australia.

OECD. (2002). Foreign Direct investment for development: maximize benefit and minimize cost. Paris: OECD Publications Service.

Oriye Agodo. (1975). The Determinants of U.S. Private Manufacturing Investment in Africa, The Graduate Scholl of Management, Northwestern University.

Pesaran, B., Pesaran, M. H. . (2009). Time Series Econometrics Using Microfit 5.0. Oxford University Press, Oxford.

Pesaran, B., Pesaran, M. H. . (2009). Time Series Econometrics Using Microfit 5.0. Oxford University Press, Oxford.

Pesaran, M., Shin, Y., \& Smith, R. . (2001). Bounds Testing Approaches to the Analysis of Level Relationships. Journal of Applied Econometrics, 16, 289-326. https://doi.org/10.1002/jae.616.

Romer P . (1993). "Idea Gaps and Object Gaps in Economic Development."Journal of Monetary Economics." Vol. 32, No. 3.

Root, Franklin R. and Ahmed, Ahmed . (1979). A. "Empirical Determinants of Manufacturing Direct Foreign Investment in Developing Countries", Economic Development and Cultural Change, 27:751-767.

Ruffin Roy J. . (1993). "The role of Foreign Direct Investment in the Economic Growth of the Asian and Pacific Region."Asian Development Review. Vol., 11, No. 1.

Salisu Mohammed . (2003). Foreign Direct Investment in Sub-Saharan Africa, The management School, Lancaster University.

Schneider, Friedrich and Bruno S. Frey. (1985). "Economic and political determinants of foreign direct investment."World Development. Vol. 13, No. 2. pp 161-175.

Seim, L. T. (2009). FDI and Openness: Differences in Response across Countries. Chr.Michelsen Institute, Working Paper.

Silajdzic, S., \& Mehic, E. . (2015). Knowledge Spillovers, Absorptive Capacities and the Impact of FDI on Economic Growth: Empirical Evidence from Transition Economies. Procedia - Social and Behavioral Sciences, 195, 614-623.

Singh, Harinder and Jun, Kwang W. . (1995). Some New Evidence on Determinants of Foreign Direct Investment In Developing Countries, The World Bank Policy Research Working Paper, No, 1531.

Solomon Mamo . (2008). Determinants of Foreign Direct Investment in Ethiopia. Thesis submitted to Maastricht School of Governance in partial fulfillment of the requirements for the degree of Master of Science in Public Policy. Maastricht, The Netherlands.

Teshome Gebre . (2010). Determinants of Foreign Direct Investment in Ethiopia. A Senior Essay submitted to Department of Economics of Arbaminch University in Partial Fulfillment of the Requirement of Bachelor of Arts Degree in Economics Arba Minch, Ethiop.

Thomas A. Puggle and Peter H. Linder . (2000). International Economics (11th edition). USA:

Todaro Michael P. . (1992). Economics for developing world (3rd Ed.). New Delhi: Longman.

UNCTAD. (1998)). World Investment Report: Trends and Determinants. United Nations Conference on Trade and Development. New York and Geneva, United Nations. .

UNCTAD. (2002). “Ethiopia: Investment and Innovation Policy Review”, United Nations.

UNCTAD. (2013). World Investment Report 2013. Retrieved December 19, 2013, From United Nations conference on trade and development: http://unctad.org/en/PublicationsLibrary/wir2013_en.pdf.

UNCTC. (1991). World Investment Report 1991: The Triad in Foreign Direct Investment. New York: United Nations Centre on Transnational Corporations. .

Wheeler, D. and Mody, A. . (1992). "International Investment Location Decisions, the Case of US firms. "Journal of International Economics, Vol. 33

World Bank . (1999). Foreign Direct Investment in Bangladesh: Issues of Long-run Sustainability.

World Bank. (2020). WWW.theglobaleconomy.com/https://www.focus-economics.com/ Ethiopia Economic Outlook.

Yared L. . (2006). Total inward and outward flows of FDI in Ethiopia. 